\title{
A Challenge to Judicial Architecture: Modifying the Regional Design of the U.S. Courts of Appeals
}

\author{
Daniel J. Meador $\dagger$
}

When Congress established the federal judicial system two hundred years ago it created three levels of courts. At the base of the system were the district courts with exclusively trial jurisdiction. At the apex was the Supreme Court, with appellate jurisdiction over lower federal courts and, in a limited way, over state supreme courts. These two levels, the top and the bottom of the judicial pyramid, have remained in place. Significant structural change, however, has taken place in the middle tier. The Judiciary Act of 1789 established the circuit courts with a mixed appellatetrial jurisdiction. ${ }^{1}$ District judges and circuit-riding Supreme Court justices presided over these courts; they had no judges of their own. Just over a century later, in the Evarts Act of $1891,{ }^{2}$ congressional architects reworked this middle tier by creating within the geographical boundaries of each of the existing circuits a United States Court of Appeals with only appellate jurisdiction and with judges of its own. Now, after passage of another century and radical changes in American life and law, regional organization is the source of increasing problems in the administration of federal law. We have come to one of those points in the evolution of American law and society when judicial architects must return to the drawing boards, this time to revisit the work of the Congress in 1891 by modifying the regional design of the federal intermediate appellate courts to fit the altered circumstances of our time. ${ }^{3}$

A radical rise in the volume of appellate business, a circum-

$\dagger$ James Monroe Professor of Law, University of Virginia. Appreciation for research assistance in the preparation of this article is expressed to Tamra Thompson, Class of 1989, University of Virginia Law School.

1 Act of Sept. 24, 1789, 1 Stat 73.

2 Act of Mar. 3, 1891, 26 Stat 826.

3 Fortunately, the judicial architects may now be in place. In December, 1988, pursuant to an Act of Congress, the Judicial Improvements and Access to Justice Act, Pub L No 100 702, 102 Stat 4642 (1988), Chief Justice Rehnquist appointed a fifteen-member Federal Courts Study Committee, with a broad mandate to examine the federal judicial system and to recommend needed changes in all of its aspects. 
stance similar to that which brought about the creation of the U.S. Courts of Appeals, necessitates modification in the structure of the intermediate tier. By 1891 it had become clear that the single Supreme Court, consisting of nine justices, was unable to stay abreast of the ever-increasing tide of appeals flowing up to it from the two sets of inferior federal courts and the state supreme courts. That was largely a quantitative problem. Quantity today has resulted in a similar but more subtle and complicated difficulty for the federal appellate system.

It is hardly surprising that the federal appellate system is encountering functional difficulties. A factory built in 1890 to produce a thousand widgets annually through manual labor and steam-powered machinery could not, in its design and size, be expected to function effectively in producing 30,000 widgets annually in the 1980s in an age of electricity and computerized processes. The factory would not merely need to be enlarged; it would need to be significantly redesigned. And so it is with the federal appellate courts. In the early 1890 s, shortly after their creation, the federal courts of appeals were receiving approximately 900 cases annually; ${ }^{4}$ today they are receiving more than 37,000 cases annually, fragmented among the twelve regional circuits and the one national circuit.

Yet the Supreme Court remains the only institutional means through which this vastly increased outpouring of decisions can be harmonized and made uniform throughout the nation. Two hundred years after its creation, that Court has appellate jurisdiction over those thirteen federal appellate courts as well as appellate jurisdiction, as to federal questions, over fifty state supreme courts, the Supreme Court of Puerto Rico, and the District of Columbia Court of Appeals. ${ }^{6}$ It is increasingly difficult, some say impossible, for a single Supreme Court of nine justices to maintain nationwide uniformity in the vast body of federal statutory and constitutional law being adjudicated in these sixty-five appellate courts.

Non-uniformity in the articulation and application of legal doctrine among so many different tribunals is not only likely but is almost a certainty. Empirical data would be interesting and helpful, but they are not necessary to an acceptance of this reality. Jus-

4 Richard A. Posner, The Federal Courts: Crisis and Reform 350 (Harvard, 1985).

- 1987 Annual Report of the Director of the Administrative Office of the United States Courts 142, 358 ("1987 Annual Report").

- 28 USC § 1254 (1982) (Court of Appeals review); 28 USC § 1257 (1982) (State Supreme Court review); 28 USC $\S 1258$ (1982) (Puerto Rico review). 
tice Joseph Story recognized it long ago in Martin $v$ Hunter's Lessee $^{7}$ in which he explained the importance of Supreme Court appellate jurisdiction over state supreme courts:

A motive of another kind, perfectly compatible with the most sincere respect for state tribunals, might induce the grant of appellate power over their decisions. That motive is the importance, and even necessity of uniformity of decisions throughout the whole United States, upon all subjects within the purview of the constitution. Judges of equal learning and integrity, in different states, might differently interpret a statute, or a treaty of the United States, or even the constitution itself: If there were no revising authority to control these jarring and discordant judgments, and harmonize them into uniformity, the laws, the treaties, and the constitution of the United States would be different in different states, and might, perhaps, never have precisely the same construction, obligation, or efficacy, in any two states. The public mischiefs that would attend such a state of things would be truly deplorable; and it cannot be believed that they could have escaped the enlightened convention which formed the constitution. What, indeed, might then have been only prophecy, has now become fact; and the appellate jurisdiction must continue to be the only adequate remedy for such evils. ${ }^{8}$

The potential for decisional disharmony today is even greater than the existence of sixty-five different courts would suggest. In each of the thirteen U.S. Courts of Appeals, there are numerous judges sitting in constantly shifting panels of three to which cases are routed on a random basis. The active judges in each circuit are frequently joined by senior judges, visiting judges from other circuits, and district judges sitting by designation, all of whom are necessary to cope with the volume of cases. This system results in hundreds of revolving and unpredictable three-judge decisional units throughout the federal intermediate appellate tier. The en banc hearing is the means for maintaining internal harmony within each circuit. ${ }^{9}$ However, growth in the number of participating judges and in the volume of litigation has made the en banc proce-

714 US (1 Wheat) 304 (1816).

3 Id at $347-48$ (emphasis in original). The same point is made in Federalist 82 (Hamilton) in Clinton Rossiter, ed, The Federalist Papers 491, 492-94 (Mentor, 1961).

- Paul D. Carrington, Daniel J. Meador, and Maurice Rosenberg, Justice on Appeal 161 (West, 1976). 
dure so cumbersome that it tends to be used relatively infrequently and thus no longer performs with full effectiveness its intended function of maintaining internal circuit uniformity. Thus, paradoxically, the more the en banc procedure is needed, the less effective it is. ${ }^{10}$ Periodic increases in the number of appellate judgeships in the existing regional framework continually magnify the Tower of Babel effect; both intra- and intercircuit inconsistencies increase. That circumstance, along with growing federal question business in the state courts, ${ }^{11}$ renders the Supreme Court increasingly ineffective in its monitoring role.

Decisional disharmony in the federal appellate structure began to be evident in the 1960s. Since then, two proposals have been advanced to create a new tribunal with nationwide jurisdiction to augment appellate decisional capacity at the top of the federal judicial pyramid. The Hruska Commission in 1975 proposed the creation of a National Court of Appeals, ${ }^{12}$ a permanent court to which the Supreme Court could refer cases for decision. Later proposals were advanced to create an Inter-Circuit Tribunal, an appellate forum to be composed of existing circuit judges sitting by designation. ${ }^{13}$ As with the Hruska Commission proposal, the Supreme Court could refer cases to this tribunal. Both of these proposed courts would have served, in effect, as overflow chambers for the Supreme Court, potentially doubling the federal appellate capacity at the top of the system, thereby enhancing the system's ability to maintain nationwide coherence in federal law. For various reasons neither proposal has been enacted. ${ }^{14}$ But the threat to the uniform-

10 Id at $161-63,200-02$.

11 See Daniel J. Meador, Federal Law in State Supreme Courts, 3 Const Comm 347 (1986) (summarizes statistical data showing, overall, an increase in federal questions before state supreme courts).

12 Commission on Revision of the Federal Court Appellate System, Structure and Internal Procedures: Recommendations for Change, reprinted in 67 FRD 195, 208-246 (1975).

13 This proposal in its various forms is described in Warren $\mathrm{E}$. Burger, The Time Is Now for an Intercircuit Panel, 71 ABA J 86 (1985); A. Leo Levin, Adding Appellate Capacity to the Federal System: A National Court of Appeals or an Inter-Circuit Tribunal, 39 Wash \& Lee L Rev 1 (1982). See also, Symposium, The Federal Courts: The Next 100 Years, 38 SC L Rev 597-98 (1987) (bibliography of articles discussing pros and cons of an Intercircuit Panel).

14 For arguments for and against these concepts see, for example, National Court of Appeals Act of 1981, Hearings on S 1529 before the Senate Subcommittee on Courts, 97th Cong, 1st Sess (1981) (National Appeals Court); National Court of Appeals Acts of 1975 and 1976, Hearings on S 2762, S 3423 before the Senate Subcommittee on Improvements in Judicial Machinery, 94th Cong, 2nd Sess (1976) (National Appeals Court); Intercircuit Tribunal of the U.S. Court of Appeals Act, Hearings on HR 4238 before the House Subcommittee on Courts, Civil Liberties, and the Administration of Justice, 99th Cong, 2nd Sess (1986) (Intercircuit Tribunal); Intercircuit Tribunal of the U.S. Courts of Appeals Act, Hearings on 
ity of federal law continues to rise, and creative judicial architects must develop other solutions.

A promising solution lies in modifying further the regional organization of the federal intermediate appellate tier by increasing the categories of appeals routed to non-regional appellate fora. These courts at the first level of review would be integrated into the intermediate tier, unlike the proposed National Court of Appeals and Inter-Circuit Tribunal. This is not a novel suggestion, but it has not received the attention it deserves. With the hope of advancing consideration of the idea, this article identifies criteria and illustrative categories of cases suitable for such appellate treatment and suggests designs for an appellate structure to accommodate such nationwide jurisdictions. First, however, it undertakes to elaborate on and clarify misconceptions about the non-regional concept of federal appellate organization and about the supposed dichotomy between generalized and specialized federal courts.

\section{Advent and Implementation of the Non-Regional, Subject Matter Concept in the Federal Intermediate ApPellate System}

The non-regional, subject matter concept as a basis for structuring a portion of the federal intermediate appellate tier can be summarized as follows: some categories of non-constitutional cases would be routed on appeal directly from the district courts to a non-regional appellate forum rather than to the twelve regionally organized courts of appeals. The decisions of that appellate forum in the categories of cases routed to it would have nationwide precedential effect and would thus eliminate the possibility of non-uniform decisions. The Supreme Court would have certiorari jurisdiction over the decisions of that intermediate appellate forum and thus would be available to set it right in the occasional case where the Supreme Court considered that the court had gone wrong. The effects of this appellate design would be to eliminate pressure on the Supreme Court to resolve intercircuit conflicts in categories routed to the nationwide forum (there being no possibility of such conflicts) and to increase the capacity of the federal judicial system to maintain nationwide uniformity in the law.

This concept of federal appellate organization was first put

HR 1970 before the House Subcommittee on Courts, Civil Liberties, and the Administration of Justice, 98th Cong, 1st Sess (1983) (Intercircuit Tribunal); Court Improvements Act of 1983, Hearings on S 645 before the Senate Subcommittee on Courts, 98th Cong, Ist Sess (1983) (Intercircuit Tribunal). 
forward in 1968 in an American Bar Foundation report. ${ }^{15}$ This report suggested a rearrangement of federal appellate jurisdiction along this line as one way of maintaining decisional harmony amidst the rising caseload and what was predicted to be, correctly as it turned out, continued substantial growth in federal appellate business. The subject matter concept was thereafter developed in a law review article written by Professor Paul D. Carrington, the reporter for that study. ${ }^{16}$

In earlier years, Congress had employed the non-regional, subject matter concept to create three courts in specific areas: the Court of Customs and Patent Appeals, ${ }^{17}$ the Commerce Court, ${ }^{18}$ and the Emergency Court of Appeals. ${ }^{19}$ Those courts no longer exist, and because of their peculiarly limited jurisdiction, they are not a model for the proposal put forth in this article. The first use of the subject matter style of appellate organization in the contemporary context came in 1971 in connection with the enactment of provisions dealing with the national energy problem. Congress then established the Temporary Emergency Court of Appeals (TECA) to which all appeals from the district courts nationwide would be taken in litigation arising under those energy regulations. ${ }^{20}$ The purpose was to ensure a national uniformity in the interpretation and application of those statutes and to provide for expeditious resolution of litigation arising under them. This court is composed of three circuit judges from the existing courts of appeals, designated by the Chief Justice. Given the limited case load of TECA, judges designated to sit on the court convene in Washington periodically to hear these appeals, but spend the rest of their time on

${ }^{15}$ American Bar Foundation, Accommodating the Workload of the United States Courts of Appeals 5 (Am Bar Found, 1968).

${ }^{18}$ Paul D. Carrington, Crowded Dockets and the Courts of Appeals: The Threat to the Function of Review and the National Law, 82 Harv L Rev 542, 604-617 (1969). This article contains one of the earliest, and perhaps the best, explanations of subject matter panels as a basis for the internal organization of an appellate court, a concept similar to the one advanced in this article. For additional discussion of internal subject matter panels in federal courts, see Carrington, et al, Justice on Appeal at 174-84 (cited in note 9).

${ }^{17} 28$ USC $\S 211$ (1982). This court was merged into the Court of Appeals for the Federal Circuit by the Federal Courts Improvement Act of 1982, 28 USC \& 41 (1982).

18 Act of June 18, 1910, Pub L No 61-218, 36 Stat 539. This short-lived court was abolished in 1913 by Act of Oct. 22, 1913, Pub L No 63-32, 38 Stat 208, 219.

19 Emergency Price Control Act of 1942, 56 Stat 23, 32 (1942) codified in 50 App USC § 924 (1982). This court was a forerunner of the Temporary Emergency Court of Appeals which replaced it. 50 App USC $\S 2166$ (1982) (terminating Act authorizing Emergency Price Control Act of 1942).

${ }^{20}$ Economic Stabilization Act of 1970 as amended by the Economic Stabilization Act Amendments of 1971, Pub L No 92-210, 85 Stat 743, 748-50. 
the appellate courts of their home circuits. ${ }^{21}$

Congress next moved to incorporate the non-regional concept into the federal intermediate appellate tier in 1982 when it created the U.S. Court of Appeals for the Federal Circuit. ${ }^{22}$ Congress created this court by fusing the Court of Claims and the Court of Customs and Patent Appeals, ${ }^{23}$ but with a substantially enlarged appellate jurisdiction. The Federal Circuit has twelve permanent judgeships, and exclusive jurisdiction over the district courts nationwide in all cases arising under the patent laws and in Little Tucker Act cases. It also has exclusive appellate jurisdiction over decisions of the Merit Systems Protection Board, certain other administrative bodies, the Claims Court, the Court of International Trade, and the newly created Court of Veterans' Appeals. ${ }^{24}$

Although designing an appellate court's jurisdiction in terms of the subject matter of cases is relatively new in the United States, such designs have long pervaded the courts of Europe. The German judiciary provides a good example. ${ }^{25}$ Since at least the beginning of the nineteenth century, all German appellate courts have been organized in this way. This scheme has been carried forward today in the Federal Republic of Germany. In its "ordinary jurisdiction" (criminal cases and private civil litigation), the appellate courts at the intermediate level are extraordinarily large by American standards, averaging seventy-three judges each. The court of last resort in that jurisdiction, the Bundesgerichtshof, has 110 judges. All of these courts avoid judicial inconsistencies by an internal subject matter organization. In the Bundesgerichtshof, for example, the judges are divided into groups of seven, with each group adjudicating appeals in several specified categories of cases and in no others; in any category of case the appeal will lie to only

${ }^{21}$ The court's business has been gradually diminishing: in 1984, forty-seven appeals were filed; in 1985, thirty nine were filed; in 1986, thirty three were filed; in 1987, eleven were filed. 1984 Annual Report at 120; 1985 Annual Report at 29; 1986 Annual Report at 28; 1987 Annual Report at 26 (cited in note 5). Largely for this reason, proposals have recently been made to abolish TECA and to transfer its jurisdiction to the Federal Circuit. See A Bill to Transfer Functions of the Temporary Emergency Court of Appeals and to Abolish Such Court, S 1146, 100th Cong, 1st Sess (1987).

${ }^{22}$ Federal Courts Improvement Act of 1982, 28 USC $\S 41$ (1982).

2s These two courts were non-regional Article III courts, but they were quite different from the Federal Circuit. The Court of Claims was a court of original jurisdiction, and the Court of Customs and Patent Appeals had a very limited appellate jurisdiction. Neither court was authorized to review any district court judgments.

24 28 USC § 1295 (1982); Veterans' Judicial Review Act, Pub L No 100-687 § 301, 102 Stat 4113 (1988).

${ }^{25}$ See generally Daniel J. Meador, Appellate Subject Matter Organization: the German Design From an American Perspective, 5 Hastings Intl \& Comp L Rev 27 (1981). 
one of the divisions of the court. Thus, conflicts among decisional units are rare. There are separate subject matter appellate courts for labor, tax, social welfare, and administrative law cases.

In the Court of Appeal of England there is also an element of subject matter organization, although it is less formalized and not as refined as that in Germany. All twenty-seven Lords Justice sitting on that appellate court have previously served on the High Court of Justice-the major trial court. ${ }^{26}$ Judges are selected from that court for the Court of Appeal based on their trial experience, in order to maintain a balance of subject matter experience in the appellate court. Thus, for example, a case in the Court of Appeal involving a family law matter would be heard by a panel of three judges who have previously served in the Family Division of the High Court. An appeal in a chancery matter would be heard by three judges who have come from the Chancery Division of the High Court. Criminal appeals are heard by judges who have come from the Queen's Bench Division of the High Court and who have presided extensively over criminal trials. ${ }^{27}$

Despite a world-wide familiarity with subject matter organization of appellate courts, such organization remains something of an unknown novelty to many American judges and lawyers. Among the state intermediate appellate courts there are a few examples; one is in Pennsylvania, where the Commonwealth Court adjudicates appeals in local government litigation and administrative law cases and the Superior Court has jurisdiction over appeals in all other civil cases and in criminal cases. ${ }^{28}$ But most Americans have not experienced this style of appellate organization, and they have not taken the time to examine other systems or to look closely at the work of TECA and the Federal Circuit. Since the late 1970's, however, the idea has been receiving increasing attention in legal literature and in professional meetings. ${ }^{29}$

The hearings and debates over the creation of the Federal Circuit $^{30}$ gave impetus to the concept of subject matter organization

${ }^{28}$ Hazell's Guide to the Judiciary and the Courts with the Holborn Law Society's Bar List 3 (1988) (listing all Lords Justice of Appeal); International Who's Who (Marquis, 1988).

${ }^{27}$ See Daniel J. Meador, English Appellate Judges from an American Perspective, 66 Georgetown L J 1349, 1376-1389 (1978).

${ }^{28} 42 \mathrm{~Pa}$ Cons Stat Ann $\S 763$ (Purdon 1981) (Commonwealth Court jurisdiction); $42 \mathrm{~Pa}$ Cons Stat Ann $\$ 742$ (Purdon 1981) (Superior Court jurisdiction).

${ }^{29}$ See, for example, Symposium, 38 SC L Rev at 363 (cited in note 13).

so Federal Courts Improvement Act of 1981, S Rep No 97-275, 97th Cong, 1st Sess (1981); Court of Appeals for the Federal Circuit Act of 1981, HR Rep No 97-312, 97th Cong, 1st Sess (1981); Federal Courts Improvement Act of 1981, Hearings on S 21 before the Sen- 
as a design that could be employed in a variety of selected federal statutory fields to accomplish two ends simultaneously: to relieve pressure on the Supreme Court to monitor intercircuit discrepancies, and to improve coherency in federal decisional law. This idea has taken on heightened importance in the wake of the failure of other proposals directed at the same problems, such as the $\mathrm{Na}$ tional Court of Appeals and the Inter-Circuit Tribunal. Further modification in the regional structure of the intermediate tier now seems the most feasible way to achieve a higher level of nationwide consistency in the law.

The most recent contribution to this ongoing discussion is a report issued in early 1989 by the American Bar Association Standing Committee on Federal Judicial Improvements. ${ }^{31}$ That report proposes that Congress and the legal profession should seriously consider the non-regional concept for incorporation, in a limited way, into the federal appellate structure.

\section{Clarification of the Non-Regional, Subject Matter Con- CEPt As Applied to the Federal INTERMediate Appellate STRUCTURE}

The jurisdiction of non-regional federal appellate courts, structured to co-exist in the intermediate tier with the regional circuits, must necessarily be defined in terms of the subject matter of the appeals. Because American lawyers and judges are generally unfamiliar with appellate jurisdiction cast in subject matter terms, they tend to confuse this concept with other ideas. Most often they confuse the concept with proposals to create a court of "experts" or a "specialized" court. Of course one could structure subject matter jurisdiction so as to fit both of those labels, but that need not be done, and that is not what is being discussed in this article. The primary purpose of a nationwide subject matter jurisdiction, as

\footnotetext{
ate Subcommittee on Courts, 97th Cong, 1st Sess (1981); Court of Appeals for the Federal Circuit Act of 1981, Hearings on HR 2405 before the House Subcommittee on Courts, Civil Liberties, and the Administration of Justice, 97th Cong, 1st Sess (1981); Court of Appeals for the Federal Circuit Act, H Rep No 1300, 96th Cong, 2nd Sess (1980); Federal Courts Improvement Act of 1979, Hearings on S 1455 before the Senate Subcommittee on Improvements in Judicial Machinery, 96th Cong, 1st Sess (1979); Federal Courts Improvement Act of 1979, S Rep No 96-304, 96th Cong, 1st Sess (1979).

${ }^{31}$ American Bar Association Standing Committee on Federal Judicial Improvements, The United States Courts of Appeals: Reexamining Structure and Process After A Century of Growth 10-24 (1989) ("ABA Committee Report"). This style of appellate organization is also discussed in Robert L. Stern, Appellate Practice in the United States 51-57 (BNA, 2d ed 1988).
} 
distinguished from a regional appellate organization, is not to create a court of experts or specialists but to maximize coherence and predictability in federal law through continuity and stability of decision makers. Perhaps this point can best be explained by considering a state judicial system in which there is a supreme court and a set of trial courts, with no intermediate appellate courts. That was the original structure in the states, and it continues to be the structure in many. In such a state, all appeals go to the single appellate forum, thus achieving a maximum degree of jurisdictionwide coherence in decisional law. Appeals in all tort cases, for example, would go to the state supreme court. The same group of judges would be deciding all tort appeals, thereby avoiding unevenness and discrepancy among various panels or courts. Yet no one has ever thought of this traditional arrangement as creating a court of experts or a specialized court in tort law. This would likewise be the situation as to all other subject matter within that court's jurisdiction: contract cases, property cases, criminal cases, administrative agency cases, and so on. In each category, a single appellate body-not composed of experts or specialists-would be deciding the appeals with a jurisdiction-wide precedential effect.

The use of the terms "generalist" and "specialist" in connection with the work of federal appellate judges is confusing and misleading. These words do not represent useful concepts in relation to the work of those appellate judges, and they interfere with realistic analysis. It is important to think anew about what federal appellate judges actually do and the varying ways that business is distributed among them. The emphasis should be on function instead of abstractions such as "generalized" and "specialized." There is a tendency to think of those federal appellate courts whose jurisdiction is circumscribed territorially - the courts of appeals for the regional circuits-as being "generalist," in contrast to those whose jurisdiction is defined only by subject matter-the Federal Circuit and TECA. To think that way, however, is factually inaccurate and functionally misleading.

To revert to fundamental principles of the American constitutional scheme, no part of the federal government, including the courts, has general powers. The federal government in all of its branches is a government of limited, delegated powers, with the residue of all governmental authority being left to the states. Federal courts cannot exercise any authority beyond that specified in Article III of the Constitution. In practice, their jurisdiction is even narrower than Article III, because we deem it necessary for Congress to authorize the jurisdiction by statute, even though Article 
III has already authorized it. Thus, federal courts have only that jurisdiction spelled out in Acts of Congress. That jurisdiction falls far short of the totality of the body of American law and the possible range of disputes that can arise under it. No federal court is a court of general jurisdiction in the common law sense or in the state court sense.

Rather than thinking in terms of "general" or "special" jurisdictions, it is more meaningful to think about federal circuit judges in relation to the range of matters in which they actually participate. No single federal appellate court (other than the Supreme Court) has jurisdiction over the entire range of federal law questions-much less over the entire range of the legal order. Consider, for example, the federal appellate jurisdiction that cannot be exercised by the twelve regional circuits: (1) cases placed in the exclusive jurisdiction of the Federal Circuit; (2) cases placed within the exclusive jurisdiction of TECA; $;{ }^{32}$ (3) three-judge district court cases that go by direct appeal to the U.S. Supreme Court. ${ }^{33}$ But withdrawing those matters from the regional circuits, thereby shrinking their range of appellate business, does not convert them into specialized courts; each retains a variety of case types, the variety differing from one circuit to another. Nor, by like reasoning, does placing the matters described in 28 USC $\S 1295$ exclusively in the Federal Circuit make that body a specialized court. In short, no one of the regional circuits or the Federal Circuit can meaningfully be described as general or special; they are courts with varying kinds of appellate business.

The Federal Circuit is not a "specialized" court in any meaningful sense of the word because 28 USC $\S 1295$ brings to that court a wide array of case types and legal issues. ${ }^{34}$ Appeals from the Claims Court, for example, include the substantive fields of tort, contract, and property, the law of damages, suits arising under the Internal Revenue Code, and a substantial mixture of statutory questions on other subjects. Appeals from the Court of International Trade present questions in still other fields of federal statutory law, commercial law, property law, and international law. Merit Systems Protection Board cases present questions in the

32 Economic Stabilization Act, 85 Stat at 748-750.

ss 28 USC \& 1253 (1982).

34 This point is well explained in Howard T. Markey, The First Two Thousand Days: Report of the United States Court of Appeals for the Federal Circuit 1982-1988 4-8 (1989). In addition to this jurisdiction, the Federal Circuit in 1989 will acquire exclusive jurisdiction over appeals from the newly created Court of Veterans' Appeals. Pub L No 100-687 § 301, 102 Stat 4113 (1988). 
field of employer-employee relationships in the governmental setting. The Federal Circuit's jurisdiction extends to district court judgments nationwide in patent and certain government claims cases, thus giving the court substantial substantive business in these fields as well as in the application and interpretation of the Federal Rules of Civil Procedure. As applied to an appellate forum with such an array of business the term "specialized" has no utility. What we are really talking about is the mixture of cases and questions in a particular court and the practical benefits of assigning some categories of federal appeals to the twelve regional courts and other categories to non-regional courts with exclusive jurisdiction over them.

Among the existing regional circuits there is already a de facto division of judicial labor along subject matter lines. The judges on one regional court of appeals have dockets that vary in significant ways from those of judges on other regional courts of appeals. The differences are often extreme; in some categories of cases there are no appeals at all in some circuits, while their number is substantial in others. In fiscal year (FY) 1987, for example, the Second Circuit had forty-one appeals in securities cases brought by the government, while the First, Sixth, Seventh, and Eleventh Circuits had none. ${ }^{35}$ The Ninth Circuit had twenty-seven appeals in real property actions against the government; the First Circuit had none. In marine injury cases, the Fifth Circuit had 180 appeals; the Sixth, Tenth, and D.C. Circuits had none. In Social Security cases, the Sixth Circuit had 252 appeals, while the D.C. Circuit had only twenty two. In environmental suits against the government, the Ninth Circuit had thirty-one appeals, while the First, Fourth, and Seventh Circuits had only one each. In prisoners' civil rights suits (excluding habeas corpus), the Fifth Circuit had 509 appeals; the D.C. Circuit had twenty three. The Ninth Circuit had 109 appeals under the National Labor Management Relations Act; the D.C. Circuit had one. This substantial variation in the nationwide distribution of appellate business shows that even without a formal allocation of appellate jurisdiction by subject matter we have a de facto division of labor on that basis. In other words, in reality not all circuit judges deal with the same kinds of cases. From this existing situation, it is a relatively short step to a more formalized and rational distribution of appellate business by types of cases.

In considering new designs for federal appellate fora, judges

35 The statistics in this paragraph are derived from 1987 Annual Report at 165-66 (cited in note 5). 
and lawyers generally agree upon at least one proposition: the structural design should be such that it does not require a federal judge to consider and decide only one, narrowly defined type of case. This view stems from concerns that judges with an overly narrow jurisdiction would become jaded and bored, that such a limited jurisdiction would not likely attract able lawyers to judgeships, that working constantly in a single narrow field would pose a risk of judicial detachment from the main body of the law and lead to arcane legal views, and that the process of choosing judges for such a narrow jurisdiction might become unusually politicized. ${ }^{36}$ The existing regional courts of appeals, the Federal Circuit, and TECA are all structured to avoid these difficulties.

In addition to underscoring the importance of avoiding an overly narrow jurisdiction, these concerns, as well as sensible judicial administration, suggest that any Article III appellate court be part of the nationwide system of U.S. Courts of Appeals and that its judges be U.S. circuit judges. Congress wisely designed the Federal Circuit in this way. Free-standing appellate courts, not integrated into the existing intermediate tier, should be avoided. Integrating new federal appellate courts into the existing intermediate tier would mean, among other things, that their judges would be eligible to sit on all other courts of appeals, and vice versa, thereby ameliorating the undesirable features of judicial work mentioned in the previous paragraph and giving a desirable flexibility in the use of judicial manpower. The creation in this fashion of additional non-regional appellate courts, whose jurisdiction is defined by subject matter, would thus be a continued elaboration of the Evarts Act of 1891.

\section{Criteria for Assigning Federal Appeals to Non-Regional COURTS}

It is axiomatic that federal law should be uniform throughout the United States. If we want a human activity to be subject to diverse and varying regulation, we leave it to the states. With rare exceptions, a major reason for a congressional enactment governing a particular matter is to ensure that it is treated the same in every part of the country. ${ }^{37}$ Any difference in interpretation and applica-

\footnotetext{
36 See, for example, Rochelle Cooper Dreyfuss, The Federal Circuit: A Case Study in Specialized Courts, 64 NYU L Rev 1, 25 (1989); Posner, Federal Courts at 147-60 (cited in note 4); Carrington, et al, Justice on Appeal at 198-200 (cited in note 9).

${ }^{37}$ In a few instances, congressional enactments look to state law to define certain terms and thus permit nonuniformity. See, for example, Federal Tort Claims Act, 28 USC $§ 2674$
} 
tion from one state or region to another undermines the political will of the nation embodied in the federal statutory enactment. But nationwide coherence in all areas of federal law cannot be achieved unless the regional appellate structure is completely abandoned. Inasmuch as that step is not necessarily desirable and is not likely to be politically feasible in the near future, the task for judicial architects is to identify those areas of federal law in which there is a special need or desirability for non-regional adjudication.

Congress has already identified several such areas by its action in consolidating appellate review into a single national forum. These include, among others, patent law, customs law, federal personnel decisions, and energy law. The first three of these are concentrated for review in the Federal Circuit; the last, in TECA. Certain characteristics of these case categories suggest why they present a special need for the kind of nationally uniform treatment that can come only through centralized appellate review.

One characteristic relates to the competitive advantages and disadvantages among litigants. Questions as to the validity of patents affect immense investments in research and production and the competitive posture of many enterprises in relation to others, much of which involves multi-state activity. Moreover, a patent is a creature of federal law, the federal government is its exclusive source. Prior to the creation of the Federal Circuit, different circuits placed varying burdens on patentees and infringers that led to rampant forum shopping and uncertainties about the validity of patents, which in turn had an adverse impact on investments in research and production. ${ }^{38}$

Similarly, customs law concerns the economic incidence of the importation of goods from foreign nations into the United States occurring at numerous ports and involving a multitude of business enterprises, many of which are in competition with each other. Different duties imposed on the same types of goods at different ports

(1982) (U.S. liable in accordance with the law of the place where the tort occurred); $D e$ Sylva v Ballentine, 351 US 570, 580-82 (1956) (state law definition of "children" in copyright act); R.F.C. v Beaver County, 328 US 204, 210 (1946) (state law meaning of "real property" in federal statute).

${ }^{38}$ For example, during the years 1945-1957, "a patent was twice as likely to be held valid and infringed in the Fifth Circuit than in the Seventh Circuit, and almost four times as likely to be enforced in the Seventh Circuit than in the Second Circuit." Dreyfuss, 64 NYU L Rev at 7 (cited in note 36) (citing Thomas Cooch, The Standard of Invention in the Courts, in William B. Ball, ed, Dynamics of the Patent System 34, 56, 59 (Central, 1960)). For a discussion of the effect of the Federal Circuit on these problems, see Gerald Sobel, The Court of Appeals for the Federal Circuit: A Fifth Anniversary Look at the Impact on Law and Litigation, 37 Am U L Rev 1087 (1988). 
would place business competitors in unequal economic positions.

Federal personnel problems involve the relationship of a single employer, the federal government, with more than two million employees nationwide, under a single set of personnel laws and regulations. The energy laws concern the regulation and use of highly important natural resources, affecting the entire population of the country in a sophisticated, technically complex way.

With the characteristics of these cases in mind, along with a realistic and common sense analysis of the American legal scene, it is possible to formulate criteria that can be used to identify other categories of cases in which there is a special desirability for the kind of nationwide uniformity in the law that can only be achieved through a non-regional appellate forum. Some of the criteria suggested below are overlapping; they can no doubt be refined, and perhaps added to with further research and analysis.

\section{A. A Nationwide Federal Program Administered By One Federal Agency}

Where Congress enacts a regulatory scheme or a program and places its administration and enforcement in a single agency of nationwide jurisdiction, it is especially desirable to have a single judicial voice to enunciate authoritatively the law under which the agency must function. A regionally organized appellate judiciary, speaking with multiple voices, tends to frustrate the congressional scheme embodied in the single agency. Uneven treatment of citizens and forum shopping for a circuit with favorable law are natural results. ${ }^{39}$ The recent report of the ABA Standing Committee pointed to the existence of a single national agency as one of the most important factors in determining categories of cases to be selected for centralized appellate treatment. ${ }^{40}$ Eliminating conflicts among multiple appellate fora and a single administrative agency would promote equitable administration of the laws, foster compliance, and assist planning by those within the agency's jurisdiction. ${ }^{11}$

B. Multi-Circuit Actors

Intercircuit conflict has a major impact on "multi-circuit ac-

30 Carrington, 82 Harv L Rev at 68 (cited in note 16); ABA Committee Report at 12-13 (cited in note 31 ).

10 ABA Committee Report at 13 (cited in note 31).

11 See id. 
tors" such as the U.S. government and large corporations. ${ }^{42}$ These multi-circuit actors have an economic incentive and the financial ability to shop for a forum to gain a particular advantage, avoid a particular disadvantage, ${ }^{43}$ or simply locate a forum where the issue has not been decided.4 Conflicts between regions result in a sense of injustice and less respect for federal law, greater advantage to multi-circuit actors, and uncertainty in circuits that have not addressed an issue. ${ }^{45}$ For these reasons, federal statutory areas that involve multi-circuit actors are good candidates for non-regional appellate review. Any additional expense involved in such centralized review is likely to be offset by the expense that otherwise would have been incurred through forum shopping and repeat litigation.

\section{Undesirable Ramifications of Non-Uniform, Regional Decisions}

Although all federal law, by definition, should be uniformly interpreted and applied, there are circumstances in which there are especially undesirable ramifications in regional disparities. Situations of economic competition present one example. Where $\mathrm{X}$ and $\mathrm{Y}$ are both engaged in similar business enterprises subject to the same federal regulation, substantial economic detriment or advantage can accrue to one or the other if that federal regulatory measure is applied to them differently. In some instances differing interpretations of the same federal law seem to work an especially egregious denial of equal protection of the laws. For example, if citizen $A$ is taxed on a transaction and citizen $B$ is not taxed on an identical transaction merely because he lives in another part of the country, our sense of fundamental fairness is offended.

The undesirable ramifications of inharmonious regional decisions may be more or less problematic depending on the objective of the law being interpreted. Uncertainty or lack of uniformity in legal doctrine is particularly undesirable when a major objective of the law is to shape future behavior. Decisional incoherence frustrates this objective where the projected activity takes place in more than one circuit or in a circuit that has not yet addressed the

42 J. Clifford Wallace, The Nature and Extent of Intercircuit Conflicts: A Solution Needed For a Mountain or a Molehill?, 71 Cal L Rev 913, 931 (1983).

43 Id at 930.

11 Todd E. Thompson, Increasing Uniformity and Capacity in the Federal Appellate System, 11 Hastings Const L Q 457, 469 (1984).

45 Id at 468. 
pertinent matter, because citizens are unable to plan with confidence a course of conduct so as to avoid running afoul of the law. ${ }^{46}$ In still another situation, where there is a vital activity, nationwide in scope and impact, such as the production and consumption of energy, differing regional interpretations of the same federal law can have a significant disruptive effect.

\section{Strength of State or Local Interests Vis-a-Vis National Interest}

In some areas of human activity, even though regulated by federal law, the state or local interest looms larger than in others, and there may be a correspondingly smaller concern about nationwide uniformity. Some environmental problems provide illustrations. Protection of marine life, for example, is not of equal interest to all states. Local concerns relating to matters such as timber, rivers, and industrial pollution may vary considerably from one region to another. The subject matter of diversity-of-citizenship litigation is another good example; almost all of those cases are governed by state law and thus the national interest is weak. In those situations there is no particular reason to divert appeals from the existing regional circuits. Those situations stand in sharp contrast to situations in which there is strong desirability of the same treatment everywhere in the country, such as management of the energy resources of the nation, validity of patents, national defense, foreign affairs, federal taxation, and numerous federal regulatory programs.

\section{E. Lack of a Critical Mass of Cases in the Regional Circuits}

For an appellate court to deal coherently and constructively with a field of law over time, the court needs more than a random case or a handful of cases annually. The judges on a particular court need to have a critical mass of appeals in order to maintain a familiarity with the law and to be able to fit each decision into a coherent pattern. If a judge deals with only an occasional case in a particular field, there is a possibility that the judge will either deal inadequately with the problem presented or will spend an inordinate amount of time educating himself in the legal setting in which the case arises. This problem is exacerbated if the relevant statute is frequently amended.

In a field of law where the appellate litigation is dispersed

16 See Dreyfuss, 64 NYU L Rev at 7 (cited in note 36). 
across numerous regional circuits, with few or no circuits having a critical mass of cases, a non-regional appellate forum would provide a means for concentrating those appeals, to ensure to a much greater degree the coherent development and application of doctrine. Because the single forum would have a relatively substantial flow of cases in a subject area, posing a variety of factual scenarios, it would not be subjected to abnormal pressure to work a major modification in the law in a single case, as is the situation sometimes in a regional circuit adjudicating infrequently in that area. With numerous appeals, the court could refine its reasoning gradually in the evolutionary common law fashion, fitting each new decision comfortably into the existing legal pattern. Moreover, economy of judicial effort would be promoted because the judges would approach each appeal in an informed way.

F. Practicability of Defining Appellate Subject Matter Jurisdiction in Unambiguous Terms

In an appellate court organized on a territorial basis, defining the court's jurisdiction is a relatively easy task. In a non-regional court, where appellate jurisdiction is defined on the basis of subject matter, delineating the court's jurisdiction can present a problem. Thus, in deciding whether a particular category of case should be routed to a single national court, one must consider the extent to which it is possible to describe the appellate jurisdiction so as to avoid significant litigation over whether the case should go to the central appellate court or to the regional circuit. This problem has been encountered in the federal circuit in relation to patent cases, ${ }^{47}$ although it does not seem to be one of long range difficulty. In any new arrangement there is likely to be a shakedown period during which refinements and adjustments are made and the lines of authority sorted out.

Some categories of cases are clearly separable from all others, but there are categories that do not lend themselves to being separated neatly for appellate treatment. For example, copyright and unfair competition claims are often linked; it would not be workable to route copyright questions to one appellate court and unfair competition questions to another. By comparison, appellate review of administrative agency orders would present no such difficulty because the statute could simply specify that all decisions and or(1988).

42 See, for example, Christianson v Colt Industries Operating Corp., 108 S Ct 2166 
ders of a certain agency would be reviewed in a designated court. If a clear-cut jurisdictional statute cannot feasibly be drafted, that is a consideration suggesting that appellate review should be left in the regional circuits. ${ }^{48}$

\section{G. Volume of Appellate Business in the Case Category}

Another practical consideration relates to the nationwide volume of appeals in the particular category of case. If the volume is such that a single court, even one with numerous judges, cannot feasibly handle the quantity of appeals, that suggests as a practical matter that appellate review be left in the regional circuits. While this is a factor to be borne in mind, it is not clear where the limit would be. As far as sheer quantity is concerned, experience indicates that the upper limit could be quite high. The U.S. Court of Appeals for the Ninth Circuit has over 5,600 appeals before it annually. ${ }^{49}$ However, there are concerns here other than sheer quantitative capacity. The primary purpose of centralizing appellate review is to maintain nationwide uniformity. If the cases are so numerous that several dozen appellate judges would be required to deal with them, the objective of uniformity may be frustrated, although even then the judicial inconsistency would be less than if the appeals were dispersed across the twelve regional circuits.

\section{Candidates for Centralized Appellate Review}

Applying the criteria and considerations discussed above, it is possible to make a modest start toward identifying at least a few categories of cases suitable for routing to a non-regional appellate forum, where decisions could be rendered with nationwide precedential effect. Building upon the modest experience thus far with patent appeals and certain other case categories in the Federal Circuit and with the appeals in TECA, we can move cautiously ahead to identify other candidates for such appellate treatment. The following categories are illustrative only; others can no doubt be identified by imaginative judicial architects through a more refined study of federal appellate dockets.

48 Additionally, it has been suggested that any subject matter area that cannot be readily separated from public policy questions should be left to regional court treatment. Dreyfuss, 64 NYU L Rev 1 (cited in note 36 ).

10 1987 Annual Report at 137 (cited in note 5). 


\section{A. Internal Revenue Cases}

Civil litigation between taxpayers and the government arising under the Internal Revenue Code presents a strong case for nonregional appellate jurisdiction. Civil tax appeals satisfy many of the criteria listed above: the extraction of taxes from citizens is administered through a single national agency (the Internal Revenue Service); regionally diverse interpretations of the tax laws work especially egregious inequities on individuals as well as on business enterprises; the national interest in uniformity clearly outweighs any local interests; tax cases do not overlap with others, so an unambiguous jurisdictional statute can be drawn.

Tax lawyers have long been aware of unresolved intercircuit conflicts in the tax field, although empirical data have not been plentiful. A recently undertaken research effort sheds new light on the magnitude of this problem. This research involved a reading of all tax cases decided in the thirteen courts of appeals from 1983 through 1987. It identified 618 cases decided by these courts on substantive income tax issues. Among those cases, the research identified thirty-three "explicit" conflicts, sixteen "implicit" conflicts, and five "sideswipes." Among these fifty-four conflicts, the Supreme Court was presented with the opportunity to resolve thirty eight. In ten of those, the Court decided the issue on the merits. In twenty six, the Court denied certiorari. In two others, certiorari has been granted, but no decision has been rendered at this writing. ${ }^{50}$

Among the twelve regional circuits, none has a critical mass of tax appeals. On the average, a typical circuit judge will deal with only a handful of tax cases each year, an insufficient number to enable that judge to achieve even a modest mastery of the field and to develop the tax law in an informed, coherent way. Yet the totality of civil tax appeals nationally could easily be handled by a single court. In the regional circuits, 826 civil tax appeals were filed

so This research has been carried out by members of the editorial board of the Virginia Tax Review. The results will be published in Volume 9 of the Virginia Tax Review (forthcoming 1989). The figures cited here are tentative and are subject to refinement before publication. The researchers define an "explicit" conflict as one where the court recognizes that another court would apply a different legal rule, but finds that rule unpersuasive or incorrect. An "implicit" conflict arises where the court unpersuasively distinguishes similar fact patterns without explicitly noting the conflict. A "sideswipe" exists where a court reaches the same result as another court, but the test or reasoning used is different and raises the possibility of future conflicts. The last term was originated by Judge Shirley M. Hufstedler. See Shirley M. Hufstedler, Bad Recipes for Good Cooks: Indigestible Reforms of the Federal Judiciary, 27 Ariz L Rev 785, 798 (1985). 
during FY 1987; twenty three were filed in the Federal Circuit.. ${ }^{52}$

For more than four decades, judges, tax practitioners, and tax professors have urged that tax appeals be concentrated in a central appellate forum. ${ }^{58}$ In the late 1970's the Department of Justice, tax lawyers, and former Commissioners of Internal Revenue united to support a bill introduced in the Senate to create such an appellate court. $^{.4}$ The recent ABA Committee Report identifies tax appeals as a promising prospect for centralized appellate jurisdiction. ${ }^{\mathbf{5 5}}$

\section{B. FCC and NLRB Decisions}

The criteria identified above collectively point toward providing for non-regional appellate review of these two agencies' decisions. ${ }^{56}$ Congress created the Federal Communications Commission (FCC) as the sole agency to carry out the federal regulatory scheme for controlling the use of the nation's airwaves by radio and television. Congress created the National Labor Relations Board (NLRB) alone to enforce the federal labor relations laws. The economic and competitive factors involved in both of these fields strongly indicate an unusual need for nationwide uniformity of treatment. The national interest in uniform treatment seems clearly to outweigh any local interest.

s1 1987 Annual Report at 105, 165 (cited in note 5).

${ }^{32}$ Letter to author from Michael L. Paup, Deputy Assistant Attorney General, Tax Division, U.S. Department of Justice, November 29, 1988. On file with the University of Chicago Law Review.

ss See, for example, Howard A. Dawson Jr., Should the Federal Civil Tax Litigation System be Restructured?, 40 Tax Notes (CCH) 1427 (Sept 26, 1988); Note, An Intercircuit Tribunal or a Court of Tax Appeals: A Tax Litigation Perspective, $11 \mathrm{~J}$ Legis 473 (1985); Posner, Federal Courts at 153 (cited in note 4); Milton Handler, What to Do With the Supreme Court's Burgeoning Calendars, 5 Cardozo L Rev 249, 275 (1984); Mortimer M. Caplin and Stuart L. Brown, A New United States Court of Tax Appeals: S. 678, 57 Taxes-The Tax Magazine, 360 (June, 1979); H. Todd Miller, A Court of Tax Appeals Revisited, 85 Yale L J 228 (1975); Henry J. Friendly, Averting the Flood by Lessening the Flow, 59 Cornell L Rev 634, 644 (1974); Henry J. Friendly, Federal Jurisdiction: A General View, 161-71 (Columbia, 1973); Carrington, 82 Harv L Rev at 608-09 (cited in note 16); Louis A. Del Cotto, The Need for a Court of Tax Appeals: An Argument and a Study, 12 Buff L Rev 5 (1963); Erwin N. Griswold, The Need for a Court of Tax Appeals, 57 Harv L Rev 1153 (1944). Just as many litigating patent lawyers objected to the creation of the Federal Circuit, many litigating tax lawyers objected to any alteration in existing appellate arrangements for tax cases.

${ }^{34}$ Tax Court Improvement Act of 1979, Hearings on S 1691 before the Senate Subcommittee on Taxation and Debt Management, 96th Cong, 1st Sess 17 (1979) (includes arguments pro and con, and arguments in support of the concept but with reservations as to the specific bill).

ss ABA Committee Report at 13-18 (cited in note 31).

so This position is taken in the ABA Committee Report. Id at $20-21$. 
During FY 1987, 154 appeals from FCC decisions were filed in the regional circuits; of these, 135 were decided by the D.C. Circuit. No other circuit had more than eight filings. ${ }^{57}$ In that same year, 561 appeals from NLRB decisions were filed in the regional circuits; several circuits each had fewer than twenty. ${ }^{58}$ The total appellate filings from these two agencies was 715 .

\section{Immigration and Naturalization Cases}

For decades, appeals in customs cases have been concentrated in one federal appellate court because of the view that goods imported from foreign countries should be subjected to the same regulation and duties regardless of the port of entry or the place of litigation. Similar reasoning, in more human terms, applies to cases arising under the immigration and naturalization laws. These laws deal with the entry and residence of persons from foreign countries. Whether a person is admitted, rejected, allowed to remain, or deported should not vary regionally. The national interest here far exceeds local interest, and these laws are administered through a single federal agency, the Immigration and Naturalization Service. Definitive, nationwide decisions rendered promptly are especially important here. For these reasons, suggestions have been made for consolidating appeals in these cases in one appellate court. ${ }^{58}$ In their totality, the number of such appeals is manageable, with 273 filings during FY 1987 in all of the U.S. courts of appeals. ${ }^{60}$

\section{Modifications in the Federal Intermediate Appellate Tier to Accommodate Additional Non-Regional Jurisdiction}

As mentioned, all appellate review in the intermediate tier of the federal judiciary should be in a U.S. court of appeals (if review is to take place in an Article III court) whose judges are U.S. circuit judges. In other words, federal appellate business below the level of the Supreme Court should be integrated into the existing system of courts of appeals, making effective management of judi-

57 1987 Annual Report at 105 (cited in note 5).

58 Id.

59 See Peter J. Levison, A Specialized Court for Immigration Hearings and Appeals, 56 Notre Dame Lawyer 644 (1981); Maurice A. Roberts, Proposed: A Specialized Statutory Immigration Court, 18 San Diego L Rev 1 (1980). As usual, objections have also been voiced to such a proposal. See Morton S. Barker, A Critique of the Establishment of a Specialized Immigration Court, 18 San Diego L Rev 25 (1980); Robert A. Juceam and Stephen Jacobs, Constitutional and Policy Considerations of an Article I Immigration Court, 18 San Diego L Rev 29 (1980).

Bo 1987 Annual Report at 105 (cited in note 5). 
cial resources more feasible and preserving the three-tiered structure. Moreover, the work of all circuit judges should be sufficiently mixed and varied to avoid apprehensions about confining the judges to an overly narrow range of matters.

The challenge here for judicial architects is to build into the intermediate appellate tier, consistently with these considerations, the desired non-regional, subject matter jurisdiction, to co-exist with the regional appellate structure. This objective can be achieved in three ways: by adding subject matter jurisdiction to existing courts of appeals, by creating new courts of appeals, or by creating a single, nationally unified court of appeals. The categories of cases just identified, along with a few others, can be used to discuss these possibilities.

\section{A. Use of Existing Courts}

There are two existing courts of appeals that are obvious possibilities for taking on some of these categories of cases on a nationwide basis-the U.S. Court of Appeals for the Federal Circuit and the U.S. Court of Appeals for the District of Columbia Circuit. The judges on each are already drawn from a nationwide pool, and each already has a substantial amount of appellate business of nationwide import. Vesting of nationwide jurisdiction in any regional circuit other than the D.C. Circuit seems undesirable because such an arrangement would place the judicial development of federal law, binding on the whole country, in the hands of judges selected from only a few states in one region.

The Federal Circuit, already organized non-regionally, is well positioned to take on additional jurisdiction of that type. Of the categories mentioned above, the Internal Revenue cases would fit most easily into its existing docket, as the court already has appellate jurisdiction over tax cases decided by the Claims Court. If the 826 civil tax appeals filed during FY 1987 in the twelve regional circuits $^{61}$ were added to the Federal Circuit's jurisdiction, that court's total annual filings would have been 2,177 instead of $1,351 .{ }^{62}$ This would not be an unmanageable enlargement of that court's docket, although it might require an increase in the number of its judgeships from twelve to fourteen or fifteen. Because the court already handles a miscellaneous variety of administrative ap-

-1 See note 51.

o2 1987 Annual Report at 358 (cited in note 5). For a review of the Federal Circuit's recent work in tax appeals, see Janet Spragens, The Tax Cases of the Federal Circuit: 1986 and 1987, 37 Am U L Rev 1141 (1988). 
peals, exclusive jurisdiction over other selected administrative areas could feasibly be added to its docket.

The District of Columbia Circuit is an obvious forum, in view of its existing business, in which to vest exclusive appellate jurisdiction over some administrative agency cases. Administrative law already occupies more than 40 percent of that court's docket. ${ }^{63}$ In view of the large percentages of all NLRB and FCC cases currently being filed there, ${ }^{64}$ it would be but a short step to vest exclusive jurisdiction over those cases in this court.65 Being already to a large extent an administrative law court whose judges are drawn from a nationwide pool, this court could also be made the exclusive forum for other agency cases.

\section{B. Creation of New Courts}

Although the use of these two existing courts is the easiest and least expensive way to increase non-regional appellate jurisdiction, the volume of cases may be such that the creation of one or more new U.S. Courts of Appeals would be desirable. The important concern in the creation of any such new appellate court is to avoid the pitfalls identified earlier of a court with too narrow a range of business. Thus, it would be important for any new appellate court to have a substantial mixture of types of cases and legal issues.

One frequent suggestion for a new appellate court with a diverse business relates to administrative agency review. Congress could create a U.S. Court of Appeals for the Administrative Circuit and place in that court a variety of administrative review business. ${ }^{66}$ In addition to NLRB and FCC cases, the court could have exclusive jurisdiction over immigration and naturalization cases, ICC cases, and any number of other types of administrative law cases. A court of this sort might have annual filings ranging from approximately 1,000 to 2,700 initially. ${ }^{67}$

63 1987 Annual Report at 105, 137 (cited in note 5). See also Gordon Bermant, Patricia A. Lombard, and Carroll Stern, The Cases of the United States Court of Appeals for the District of Columbia Circuit 3-4, 43-46 (Fed Judicial Center, 1982).

${ }^{64}$ See notes 57 and 58.

6s This move is suggested in ABA Committee Report at 27-28 (cited in note 31).

${ }^{88}$ See, for example, Ellen R. Jordan, Specialized Courts: A Choice?, $76 \mathrm{Nw}$ U L Rev 745, 765-67 (1981); Thomas O. McGarity, Multi-Party Forum Shopping for Appellate Review of Administrative Action, $129 \mathrm{U} \mathrm{Pa} \mathrm{L}$ Rev 302, 356-60 (1980). Other proposals have been made to create a set of administrative law courts that would be Article I courts and would provide review in a wide range of administrative agency cases. See, Department of Justice Committee on Revision of the Federal Judicial System, The Needs of the Federal Courts 7-11 (GPO, 1977).

${ }^{87} 1987$ Annual Report at 105 (Filings for NLRB (561), FCC (154), INS (273), and ICC 
Suggestions have often been made that a new appellate court be created for tax appeals. ${ }^{68}$ Tax cases present a sufficient array of issues to avoid the undesirable pitfalls of an overly narrow jurisdiction, even though they arise solely under the Internal Revenue Code. As with any new federal appellate court, it would be important to create the court as a U.S. court of appeals-called, for example, the Revenue Circuit-with U.S. circuit judges, so that the forum would be integrated into the intermediate tier. Given the current volume of tax appeals, initially a court of five circuit judges would be adequate. However, considering all factors, the appellate structure might be served better by routing all tax appeals to the Federal Circuit. The Federal Circuit already decides some two dozen tax cases annually (those coming on appeal from the Claims Court) and such an arrangement would eliminate the need for a new court.

Another way to create a new non-regional court would be along the lines of TECA. However, a court without judges of its own, depending on judges from other circuits sitting temporarily by designation, has administrative and logistical problems that can be avoided by the use of permanent courts. It makes little sense, for example, to maintain a clerk's office, as is currently done for TECA, for a court with no more than a dozen or so appeals annually. ${ }^{68}$ If the appellate volume were much greater, however, the drain on the existing circuits resulting from designations of their judges to such a court would be substantial. The TECA model might best be reserved for truly temporary, emergency situations.

Military cases, broadly defined, form a discrete category that could sensibly be routed to a non-regional forum. At present, appellate review of court martial convictions, after affirmance by one of the armed services courts of military review, is vested in an Article I court composed of three civilian judges, the U.S. Court of Military Appeals. ${ }^{70}$ A suggestion has been made to provide Article III appellate review for those cases. ${ }^{71}$ If Article III review is desired, it

(74) totaled 1,062. All agency appeals totaled 2,723) (cited in note 5).

${ }^{68}$ For suggestions as to the form that such an appellate court might take, see notes 53 and 54.

Bo In the 100th Congress, a bill was introduced to abolish TECA and transfer its jurisdiction to the Federal Circuit, thereby eliminating the expense of maintaining TECA's separate clerical staff and the logistical problems of assembling judges periodically from around the country. See note 21. This proposal has been endorsed by the American Bar Association. Recommendations and Report to the House of Delegates, American Bar Association, Section of Administrative Law, approved by the House of Delegates, Feb. 1985.

${ }^{70}$ Uniform Code of Military Justice, 10 USC $\$ 867$ (1982).

"See, for example, Robinson O. Everett, Some Observations on Appellate Review of 
should be provided through a court integrated into the intermediate tier and perhaps denominated the U.S. Court of Appeals for the Military Circuit. This court's jurisdiction could include other types of cases. ${ }^{22}$

Appeals in military related cases that are now scattered across the regional circuits could be concentrated in the Military Circuit. Such cases include appeals from district court judgments in habeas corpus proceedings attacking the validity of courts martial, actions in the district courts for allegedly illegal administrative discharges, suits for back pay on behalf of military personnel, and assorted other cases involving the armed services. Thirty appeals in those types of cases were decided by the regional circuits during $1987 . .^{73}$ Petitions to review court martial convictions in the Court of Military Appeals in recent years have ranged from 2700 to 3200 annually. ${ }^{74}$ The court has discretionary authority to grant or deny these petitions; as a result, it has been deciding annually between 145 and 318 court martial appeals on their merits. ${ }^{75}$ Those cases combined with appeals in military related cases coming from the district courts would make a manageable docket for a court of five circuit judges. On the other hand, non-regional, Article III review could be provided by channeling all of these cases to the Federal Circuit, with a slight enlargement in the number of its judges. That court already adjudicates the validity of court martial proceedings in the course of deciding appeals in back pay suits coming to it from the Claims Court.

\section{A Nationally Unified Court of Appeals}

Instead of using existing courts or creating new courts, a bolder more imaginative way of restructuring the intermediate tier would be to unify the thirteen existing courts into a single, nationwide U.S. Court of Appeals. Such a structure would be in line with

Court-Martial Convictions-Past, Present and Future, 31 Fed Bar News \& J 420 (1984). The proposal is discussed but not endorsed in U.S. Court of Military Appeals Committee Report 21 (Jan 27, 1989). The Defense Department has recently stated its opposition to the proposal in Report of the Department of Defense Study Group on the United States Court of Military Appeals (July 25, 1988).

${ }^{2}$ A suggestion to that end has been made by the present Chief Judge of the Court of Military Appeals. Everett, 31 Fed Bar News \& J at 422 (cited in note 72). See also Daniel J. Meador, Federal Judicial Review of Courts Martial Convictions-A Proposal for Reform (Sept 27, 1986) (paper delivered at Seminar on the U.S. Courts and National Security, Charlottesville, Virginia).

${ }^{23}$ U.S. Court of Military Appeals Committee Report at 22 (cited in note 71).

74 Id at 17.

75 Id. 
the twentieth century movement toward unification of court systems generally, thereby avoiding dysfunctional fragmentation, making possible more effective management of judicial resources, and maximizing flexibility as circumstances change. Provision should be made for this nationwide court of nearly 200 judges to sit in divisions. These internal divisions should not be rigidly fixed by statute; rather, authority to designate divisions could be vested in the court's chief judge and its executive committee of judges, or it could be vested in the Judicial Conference of the United States (which would probably need to be somewhat reorganized to reflect this new intermediate structure).

The internal divisions of this single nationwide court could blend the regional and non-regional appellate allocations of business along the lines already discussed. The regional divisions might approximate the present circuit lines, although circuit lines as such would be abolished. To make it clear that a rigid territorial jurisdictional structure was being abandoned, the new regional divisions might be designated by names such as Northeastern Division, Southeastern Division, Midwest Division, and so on, all drawn so as to equalize appellate business and avoid such disparate allocations as those presently existing, for example, between the First and Ninth Circuits. Imagination could devise titles that would generally identify the region covered by the division, but would leave a flexibility to reshape divisional lines administratively as the ebb and flow of appellate business seemed to justify.

In addition to territorial divisions, subject matter divisions could embrace the types of business described above in connection with proposed new courts. For example, there could be an Administrative Division, a Revenue Division, a Claims and Personnel Division, and so on. It would be necessary, of course, to identify types of appeals appropriate for the regional divisions and those appropriate for non-regional review. Divisions could be created or abolished and their business changed administratively from time to time without the necessity of new congressional enactments. Each division would have a chief judge to oversee its internal administration; that judge would be responsible to the chief judge of the entire court and its executive committee.

The judges on this court would be circuit judges serving on the U.S. Court of Appeals, without specification of circuit or division. As new judicial manpower is needed, in light of the totality of federal appellate business, Congress would add judgeships to the court without specification of division. A new judge appointed to the court would be assigned by the court's chief judge or executive 
committee to the division where an additional judge is needed. A judge could be reassigned from time to time from one division to another to respond to the needs of the system. Given the nature of the nominating and confirming process in the selection of federal judges, it is highly likely that geographical considerations would continue to play an important part in filling most of these judgeships; the distribution of circuit judges throughout the country would not differ greatly from the existing pattern.

A nationally unified court at the intermediate level would make it feasible for inter-regional inconsistencies to be resolved without resort to the Supreme Court. Provisions could be made within this court for an en banc panel to hear and decide conflicts between the regional divisions. This national en banc panel would be composed of a specified number of circuit judges (nine or eleven, for example) designated either by the court's executive committee or by the Supreme Court.

Obviously, many details remain to be worked out to implement a design of this sort, and the undertaking would call for a high degree of creativity in judicial architecture. Yet, a unified appellate court of this sort may, in the long run, be the most promising approach to putting in place an intermediate appellate tier that can best equip the federal system to deal with unforeseen and ever changing business.

\section{Federal Judicial Review of State Cases}

Direct review of federal questions in the decisions of the highest courts of the states is now and always has been exclusively within the jurisdiction of the United States Supreme Court. ${ }^{76}$ However, the regional circuits do play an indirect part in providing federal review of state court decisions because they review federal district court judgments in habeas corpus cases brought by convicted state prisoners. ${ }^{77}$ The Supreme Court, in turn, has certiorari jurisdiction over those courts of appeals decisions as it does over all courts of appeals decisions. ${ }^{78}$ Thus, ultimately all state cases involving federal questions are reviewable in the Supreme Court, and it is the only appellate court that can decide those questions with nationwide precedential effect.

The problem here is somewhat different from that previously

\footnotetext{
7828 USC § 1257 (1982). Judiciary Act of 1789, 1 Stat 73, 85-87.

7728 USC §§ 1291, 2254 (1982).

${ }^{78} 28$ USC § 1254 (1982).
} 
discussed. It is not primarily one of maintaining uniformity in federal statutory interpretations among the regional courts of appeals. Rather, the problem stems from limitations on the Supreme Court's capacity to provide adequate appellate review and thus to maintain uniformity on federal questions in the cases coming from the fifty state systems, the District of Columbia, and Puerto Rico, as well as in the state habeas corpus cases from the twelve regional U.S. Courts of Appeals.

The Supreme Court's appellate capacity in this regard is being increasingly strained by the growing amount of federal law involved in state court litigation, coupled with the rise in the volume of litigation in the state courts. Two developments over the last few decades have substantially increased federal law questions in the state courts: the Supreme Court's expansive interpretation of the provisions of the Fourteenth Amendment, and Congressional enactment of many statutes creating rights of action enforceable in state courts as well as in federal courts. One survey showed that the proportion of state supreme court decisions involving federal law rose more than three-fold between 1959 and 1979.79 Another survey showed that in 1983, an average of 28 percent of state supreme court decisions involved federal questions. ${ }^{\mathbf{8 0}}$

Proposals have been made in the past to increase the federal judiciary's capacity to review this ever growing array of federal questions being adjudicated in the highest state courts. The thrust of these proposals has been to establish a new federal appellate court to which state cases would be routed in the first instance, with review available thereafter on certiorari in the Supreme Court. ${ }^{81}$ The possible desirability and the constitutionality of such an arrangement were foreseen in The Federalist Papers even before ratification of the Constitution. ${ }^{82}$ This objective could and should be accomplished through the creation of a court integrated into the existing courts of appeals structure. It could be called the U.S. Court of Appeals for the State Circuit; if a nationally unified

79 National Center for State Courts, Comparison of Federal Legal Influences on State Supreme Court Decisions in 1959 and 1979, reprinted in Legislation for Improvement of the Judiciary, Hearing before the Senate Subcommittee on Courts of the Committee on the Judiciary, U.S. Senate, 97th Cong, 2nd Sess 293 (1982).

so Meador, 3 Const Comm at 351 (cited in note 11).

s1 See, for example, James Duke Cameron, Federal Review, Finality of State Court Decisions, and a Proposal For a National Court of Appeals, 1981 BYU L Rev 545; Clement F. Haynsworth Jr., A New Court to Improve the Administration of Justice, 59 ABA J 841 (1973) (argues that federal habeas corpus should be replaced by a national court to review federal questions arising in state courts).

s2 Federalist 82 in Federalist Papers at 494-95 (cited in note 8). 
court were established, it could include a State Division for this purpose. All of the Supreme Court's direct appellate jurisdiction over state court decisions would be transferred to this new court or division. In addition, all appeals of state prisoners' habeas actions from district court decisions could be routed to this forum, rather than to regional circuits.

The docket of this proposed new court would be largely discretionary. During the 1987 Term, there were 1,201 cases coming to the Supreme Court from the fifty state court systems, the District of Columbia, and Puerto Rico. ${ }^{83}$ Although these involved a mixture of appeals and certiorari petitions, because of the recent repeal of the mandatory appellate provisions, ${ }^{84}$ review in all such cases will be sought hereafter by petition for certiorari. Appeals presently coming to the regional circuits in state habeas corpus cases all require a certificate of probable cause for appeal, thus affording courts a substantial measure of discretion in dealing with them. ${ }^{\mathrm{ss}}$ In FY 1987, there were 2,755 such appeals. ${ }^{86} \mathrm{~A}$ court composed of nine circuit judges should be able to cope adequately with such a discretionary docket.

Because this court would be taking over the function of the Supreme Court in providing direct review of the judgments of the highest state courts, it would be desirable for the court to sit en banc, just as the Supreme Court now does, when deciding such cases on their merits. This would give its judgments greater dignity and precedential weight than they would have if three-judge panels were employed, and such an arrangement would accord greater respect to the state supreme courts. In deciding whether to grant or deny certiorari petitions, however, this court could, of course, adopt the Supreme Court's rule of four. Moreover, in reviewing district court decisions in habeas corpus cases the court could reasonably sit in three-judge panels, as the regional circuits now do.

\section{OBJECTIONS}

Proposals to create or to enlarge non-regional federal appellate 1988

8s This figure was supplied to the author by the Clerk of the Supreme Court, November

st Review of Cases by the Supreme Court, 102 Stat 662 (1988) to be codified at 28 USC $\S 1254$ (1988). See Robert L. Stern, Eugene Gressman, and Stephen M. Shapiro, Epitaph for Mandatory Jurisdiction, 74 ABA J 66 (1988).

${ }^{85} 28$ USC § 2253 (1982).

${ }^{86} 1987$ Annual Report at 143 (cited in note 5). 
jurisdiction easily encounter opposition from the bench and the bar. Much of the opposition is rooted simply in the novelty of the idea. Without regard to facts, needs, or realities, members of the legal profession tend to react negatively to proposed jurisdictional and structural arrangements with which they are not familiar. As time passes and as the work of the Federal Circuit becomes better known, some of this opposition may recede. But instinctive aversion to the new and unfamiliar will no doubt remain. Moreover, apart from instinctive opposition there are arguments made against movements away from the regional appellate structure. These arguments, briefly recapped below, are typically heard at judicial conferences, bar meetings, and informal discussions whenever such proposals are advanced; they are only sparsely treated in the legal literature.

\section{A. Percolation}

With twelve regional circuits having appellate jurisdiction over the same categories of cases, we will get a diversity of views brought to bear on the same legal questions in the same field of law. A particular issue will "percolate" for some time before it is definitively resolved on a nationwide basis. This, so the argument runs, is good because it permits a variety of perspectives to be brought to bear on the question and provides the ultimate decision maker (the Supreme Court) with the benefits of the analyses and wisdom of numerous judges with diverse approaches.

This argument has its greatest force in relation to constitutional questions. The Supreme Court's decision on the meaning of a constitutional provision is difficult, if not virtually impossible as a practical matter, to change; it can only be changed through the cumbersome process of amending the Constitution by the action of both Houses of Congress and of two-thirds of the state legislatures or the even more awkward process of a constitutional convention. Thus it is important that the Supreme Court have the benefit of as much thinking on the question as is feasible before it makes this final resolution.

But the percolation argument loses most of its force when applied to questions of federal statutory interpretation. There Congress has spoken on the matter, and it is important for the judiciary to implement congressional intent in a straightforward, clear manner without generating uncertainties over a prolonged period of time. If the judiciary misspeaks the will of Congress, Congress sits to set the matter straight. This is one of those situations in which it seems more important that the matter be settled than 
that it be settled "right." Congress, in any event, can determine what is "right" on any aspect of its enactments.

As applied to judicial interpretations of federal statutes, "percolation" is a euphemism for incoherence. The argument has the earmark of being an effort to put a good face on a bad situation. Whatever modest value there may be in these regional discrepancies as to federal statutory provisions, the benefit is outweighed by the cost to the system and to American citizens. The statutory questions involved are typically not earthshaking; indeed, they often involve quite narrow points. Yet they are important to persons affected by them and to those who must plan and conduct activities, especially those engaged in activities stretching across circuit lines. The percolation that produces intercircuit inconsistencies and incoherence may provide intellectual stimulation for academicians, but in the world of human activity it works costly inequities.

\section{B. The Specialization Bugaboo}

An aversion to specialized courts is deep seated in the American legal psyche. It surfaces instinctively and unthinkingly whenever a proposal for a nationwide federal appellate forum is mentioned. As already mentioned, this objection misconceives the concept being discussed here and also reflects an inadequate understanding of the work actually being done by Federal Circuit judges. Without repeating all that has been said before, it should suffice to restate the point that an appellate court with a nationwide, subject matter jurisdiction need not be a court of "specialists" and that in reality no federal circuit judge today is truly a "generalist." The only way that federal circuit judges could hope to sit on the entire range of appeals, in all subject areas under federal law, and thus come closer to being generalists, would be to rotate periodically among all thirteen circuits and make certain that in each circuit they sat on appeals missing from their own and other circuits. This is, of course, impossible as a practical matter. We have, and will continue to have, judges on the regional courts of appeals who sit on varying mixtures of subject matter, differing from one circuit to another. No one of these judges is a generalist or specialist; they simply have differing dockets of differing types of cases. So long as federal appellate judges have a significant mixture of legal questions coming before them, as they do at present and as they would have under any of the proposals discussed in this article, it is pointless to debate the abstractions of generalized and specialized courts. 


\section{Political Control}

There is concern that a court whose jurisdiction is limited to a narrow range of subject matter may be more susceptible to control and influence from the political branches of government than is a court with broader jurisdiction. ${ }^{87}$ Such political influence, in relation to an Article III court, might come in two ways: through the selection of persons to serve as judges on the court, and through congressional control of the court's budget and an increased degree of congressional oversight of the court. It is difficult, however, to see how a U.S. court of appeals with non-regional subject matter jurisdiction could be rendered less independent by a greater measure of congressional interest in its work. Budget requests for all U.S. courts of appeals are submitted together by the Judicial Conference of the United States. The salaries of all U.S. circuit judges are the same, provisions for law clerks and other support personnel are essentially on the same basis. Congress could, of course, single out a particular court for deprivation of resources, such as denying it necessary physical facilities and support personnel, but the likelihood of the exercise of such authority seems quite small as a practical matter. As for increased intensity of congressional oversight, it is difficult to see how this would impair the court's independence in light of the fact that the judges hold office during good behavior and have their salaries constitutionally protected against reduction. The substantial congressional hostility manifested toward the Supreme Court from time to time in our history does not appear to have impaired that court's independence.

The Federal Circuit provides a good test case. There is no evidence to suggest that the independence of that court has been impaired. There may be intense congressional interest in patent law and in other areas of that court's exclusive jurisdiction, but nothing so far indicates that such interest has been translated into congressional action of a punitive sort. Another good test case is provided by the U.S. Court of Military Appeals, an Article I court. Such a non-Article III tribunal is more vulnerable to Congressional control and influence than an Article III court. However, there is no evidence that the substantial interest in this court within the Armed Services committees of the Congress has had any significant influence over that court's decisions or on its budget, nor has Congress taken any punitive measures against it.

87 An argument to this effect is presented in Posner, Federal Courts at 154-55 (cited in note 4). 


\section{Washington-Based Courts}

Any newly created non-regional court of appeals is likely to be located in Washington, D.C., so an argument runs, with two undesirable consequences, at least from the standpoint of practicing lawyers throughout the country: its judges will be drawn disproportionately from Washington, D.C. ${ }^{88}$ and practice in the court will be a monopoly of the D.C. bar. While all of this is a possibility, none of it need be so if new courts are created.

There is no particular reason why a new non-regional federal appellate court must be based in Washington. Indeed, there is much to be said for locating such a court elsewhere. There is, from many perspectives, already too much government located in and around the District of Columbia. In the age of jet air travel, a U.S. court of appeals serving the entire nation could just as well-or better-be located in some other centrally positioned city, such as St. Louis or Memphis or, to give the western region of the country a larger share of federal institutions, in Denver. The main consideration would be proximity to a major airport. It is just as easy for lawyers in San Francisco and Atlanta, for example, to fly to St. Louis for an oral argument as it is to fly to Washington.

Even if a new federal appellate court is based in Washington, it could sit at regular intervals in other cities throughout the United States. A statute authorizes the Federal Circuit to do this, ${ }^{89}$ and it has done so several times. If feelings ran strongly enough about this point, the new court could be expressly required by statute to sit at stated intervals in designated cities elsewhere.

If the new court did sit periodically in other cities or if it were housed permanently in a city other than Washington, apprehension about a District of Columbia bar monopoly on practice in the court should be dispelled. That apprehension should also be diminished in this era of national law firms in which firms in all parts of the country maintain their own Washington offices.

As to judgeships, the District of Columbia Circuit demonstrates that being housed in Washington does not mean that Washington lawyers will predominate as judges on the court. Of the eleven active judges presently on the D.C. Circuit, only two could arguably be said to have come from the Washington bar. The others came from all parts of the country. Indeed, in recent years complaints have been voiced recurrently from Washington lawyers

${ }^{88}$ Id at 156.

B9 28 USC \& 48 (1982). 
that so few are being appointed to the D.C. Circuit.

\section{E. Filling Judgeships}

Selecting judges is the other way in which the two political branches can seek to exert control over a court. The argument is that the more narrow a court's jurisdiction the greater the likelihood of undesirable and sharply focused political considerations in the choice of judges. There is much truth in this proposition. But such undesirable ramifications of the selection process can be avoided by giving the Court jurisdiction beyond a single, highly specialized area. A variety of interests on different sides of several sets of legal issues should provide reasonable protection against sharply focused ideological fights for judicial appointments, at least to the extent that such fights are avoided in appointments to the regional circuits. Apart from concern about the politicizing of judicial appointments, there is an argument that it would be diffcult to attract able lawyers to fill judgeships on a federal appellate court other than one of the regional circuits. The argument is rarely fleshed out by those who make it, and the reasons underlying it are not readily apparent. The argument seems to stem from the misconceptions discussed previously concerning the nature of the proposed non-regional courts. There is indeed reason to believe that an appellate court with jurisdiction limited to a narrow set of issues in a single field of law might not present an attractive career prospect. But it is unrealistic to think that among the thousands of lawyers practicing in the various areas of administrative law, tax law, and other federal fields-in addition to numerous federal district judges-there are not ample numbers with the requisite integrity and competence who would be attracted professionally by the prospect of being a United States circuit judge on an appellate court of nationwide scope. The most pertinent experience to date is provided by the Federal Circuit and, to a lesser extent, by the D.C. Circuit. Although one may quarrel with some of the choices of judicial nominees made by those who select the judges for these two courts, there is no evidence that judgeships on them have been any more difficult to fill than judgeships on the purely regional circuits. Indeed, judicial recruitment is likely to be easier because the pool of potential nominees is national, not regional, and no Senator has any special state-oriented political interest in the judgeships.

\section{F. No Problem}

It is often difficult to tell whether the assertion that there is 
"no problem" in the federal appellate system that needs fixing is a cover advanced by those with other objections to an appellate jurisdiction nationwide in scope or whether it reflects a considered and informed judgment that there really is no problem. In any case, the argument that there is no problem is, unfortunately, often effective in diverting discussion from the merits of the concept of non-regional federal appellate courts.

Taken on its merit, the "no problem" argument is thin. Two centuries ago, the authors of The Federalist Papers foresaw the inevitability of non-uniformity among multiple courts, ${ }^{90}$ and Justice Story later reasserted that obvious insight.. ${ }^{91}$ As described earlier, beginning in 1968, the problem of discrepancies among decisions of the regional circuits has been the focus of major attention among able judges, lawyers, and legal academicians. The American Bar Foundation study, ${ }^{92}$ the Freund Committee, ${ }^{93}$ the Hruska Commission, ${ }^{94}$ the Advisory Council on Appellate Justice, ${ }^{96}$ the Justice Department's Office for Improvements in the Administration of Justice, ${ }^{96}$ the ABA Standing Committee on Federal Judicial Improvements, and numerous individuals ${ }^{97}$ over a period of twenty

90 Federalist 82 in Federalist Papers at 493-94 (cited in note 8).

${ }^{91}$ Martin $v$ Hunter's Lessee, 14 US (1 Wheat) at 347-48. See also text accompanying note 8.

92 American Bar Foundation, Accommodating the Workload at 6-7 (cited in note 15).

${ }^{93}$ Report of the Study Group on the Caseload of the Supreme Court, 57 FRD 573 (1972).

94 Structure and Internal Procedures, 67 FRD at 208-46 (cited in note 12).

${ }_{95}$ This group of thirty judges, lawyers, and academicians, chaired by Professor Maurice Rosenberg, functioned from 1971 to 1975 as an advisory body on appellate matters to the Federal Judicial Center and the National Center for State Courts. Its work culminated in a National Conference on Appellate Justice in 1975. Materials prepared for that conference and portions of the conference proceedings were published in five volumes entitled Appellate Justice: 1975. Volume IV discusses federal appellate courts and revision of the federal court structure to resolve workload and consistency concerns.

${ }_{96}$ The work of this office in this regard culminated in the proposal, introduced in the Senate in 1979, to create the U.S. Court of Appeals for the Federal Circuit. Daniel J. Meador, Role of the Justice Department in Maintaining an Effective Judiciary, in A. Leo Levin and Russell R. Wheeler, eds, 462 The American Judiciary: Critical Issues 136, 143-44 (Sage, 1982).

${ }^{97}$ See, for example, Note, $11 \mathrm{~J}$ Legis 473 (cited in note 53); Thompson, 11 Hastings Const L Q 457 (cited in note 44); Handler, 5 Cardozo L Rev 249 (cited in note 53); Wallace, 71 Cal L Rev 913 (cited in note 42); Roberts, 18 San Diego L Rev 1 (cited in note 59); Conrad K. Cyr, Structuring a New Bankruptcy Court: A Comparative Analysis, 52 Am Bankr L J 141 (1978); Charles R. Haworth and Daniel J. Meador, A Proposed New Federal Intermediate Appellate Court, 12 Mich J L Reform 201 (1979); Miller, 85 Yale L J 228 (cited in note 53); Friendly, 59 Cornell L Rev 634 (cited in note 53); Shirley M. Hufstedler, Courtship and Other Legal Arts, 60 ABA J 545 (1974); Maurice Rosenberg, Planned Flexibility to Meet Changing Needs of the Federal Appellate System, 59 Cornell L Rev 576 (1974); Scott C. Whitney, The Case for Creating a Special Environmental Court System, 14 
years have thought that there is a significant difficulty in maintaining uniformity and coherence in the appellate decisions of the federal courts. Even if a person were not disposed to believe this himself, the array of distinguished legal minds arriving at that conclusion after a series of studies over a long period of time should be enough to persuade one, at least prima facie, that there is indeed a systemic malfunction that needs correcting.

There are persons who agree that there are conflicts, discrepancies, and incoherences among the decisions of the various federal circuits, but they respond that such a situation is not necessarily bad. The disturbing feature of this position is that it involves an assault upon the concept of law itself. One of the most basic features of law is that it embodies a set of rules and principles applicable to everyone in like manner throughout the jurisdiction it purports to govern. A judicial system that produces legal doctrine differing because of the happenstance of the place of litigation and of the particular judges sitting on the case is hostile to the reign of law. A situation of this sort grew up under the doctrine of Swift $v$ Tyson, ${ }^{98}$ and its intolerability led to its overthrow in Erie R. Co. $v$ Tompkins. ${ }^{99}$ When these doctrinal discrepancies involve statutory provisions, they present the added problem of the judiciary's frustrating the legislative will.

There seem to be at least three possible explanations as to why anyone would support a situation so obviously hostile to the concept of law. One is that a growing proportion of today's lawyers and judges came into the legal profession at a time when regional incoherence of federal decisional law had already begun to appear; thus, they have never known the system to be otherwise and are less likely to see regional discrepancies as an abnormality. Another explanation probably lies in the legal realism movement taken to its extremes, as in critical legal studies. Those enamored with that view have little belief in law as a known and predictable set of conduct-governing rules and therefore do not expect the judiciary to produce a coherent array of doctrinal decisions. A third explanation may lie in a vague distrust of judges-a distrust among lawyers as well as among judges themselves. Such an attitude leads to the view that it is undesirable for one group of judges (with the apparent exception of the Supreme Court) to make decisions with

Wm \& Mary L Rev 473 (1973); Carrington, 82 Harv L Rev at 604-617 (cited in note 16); Del Cotto, 12 Buff L Rev 5 (cited in note 53); Griswold, 57 Harv L Rev 1153 (cited in note 53).

${ }^{98} 41$ US (16 Pet) 1 (1842).

2? 304 US 64 (1938). 
nationwide precedential effect; rather, it is better to have random groups of judges deciding the same questions, with no group bound by any other.

Although both lawyers and judges may hold this view, they do so for different reasons. Litigating lawyers desire to keep open the maximum array of options, with the hope of a favorable outcome in any given case despite an adverse holding by some judicial threesome in a prior case. Among appellate judges this view may rest in part on ego and a desire to have an opportunity, at least theoretically, to have a shot at any and all questions that may be generated in federal litigation. Needless to say, such views among lawyers and judges can hardly afford a sound basis on which to construct an appellate system to serve the entire United States.

Whatever the explanation for the casual regard for non-uniformity in federal statutory interpretations, that attitude threatens the rule of law as we have traditionally conceived it. It is difficult to believe that thoughtful judges and lawyers are willing to accept widespread-and likely growing-denials of equal protection of the laws, varying advantages and disadvantages to American citizens under federal law depending on one's residence, and the frustration of the political will of the American people speaking through Congress. Yet that is the result of an acceptance of the judicial Tower of Babel produced by an appellate system with overreliance on regionally organized courts with ever growing numbers of judges deciding an ever swelling number of cases, through constantly shifting three-judge panels with randomly assigned dockets, subject only to the remote possibility of Supreme Court review.

\section{A SUmming UP}

Judicial structures, jurisdictions, and processes have all evolved over time. None of these has been or can be unchanging. In England, the dispute-resolving functions of the Curia Regis in the twelfth century gradually gave birth to the common law courts and the Court of Chancery. Those tribunals in turn were restructured in the nineteenth century into a unified trial and appellate court. The judicial systems that came into being in North America during the seventeenth and eighteenth centuries matured into the state court systems, and the federal judicial system was designed and put in place after the ratification of the Federal Constitution. These systems have all evolved over the past two hundred years. One of the most significant of their structural alterations has been the insertion of an intermediate appellate tier, a set of appellate courts between the broad base of trial courts and the court of last 
resort. In the federal system the intermediate appellate tier, unlike that in many states, was organized on a regional basis, resulting today in twelve separate U.S. courts of appeals each having jurisdiction over district court decisions within a defined geographical territory. When that system was put in place, before the dawn of the twentieth century, it made sense and posed no significant problems. Movement of people and goods was slow; railroads afforded the fastest means of transportation over the vast transcontinental distances. Nationwide or multi-state business enterprises were relatively few. A court of appeals in each geographical region of the country fit well with the conditions of the time. Moreover, the volume of litigation was such that the United States Supreme Court could review a substantial number of these appellate court decisions and thus could effectively maintain nationwide harmony in federal decisional law. All of these circumstances have changed. Jet airplanes now transport persons and property from coast to coast between breakfast and lunch. The telephone and electronic mail now convey messages and information instantaneously. Millions of persons are in motion across the width and breadth of the country daily. Enterprises of all sorts do regular business across many states. The volume of appeals being adjudicated in the regional appellate courts has swollen enormously, and the number of judges has likewise been increased. The state supreme courts are collectively deciding more federal questions than could have been remotely imagined a century ago. Correspondingly, the capability of the Supreme Court to review a significant proportion of the decisions of these sixty-five appellate courts-state and federal-has decreased markedly, thus blunting the effectiveness of the only existing means of maintaining a reasonable degree of nationwide harmony in federal law. In short, the structure designed in 1891, entirely adequate then and well adapted to the circumstances of that era, is no longer functioning effectively under the changed conditions of the late twentieth century. To meet these altered circumstances and to overcome the difficulties now evident in the intermediate appellate tier, there is little that can be done through alterations in the Supreme Court. Its decisional capacity cannot be increased significantly ${ }^{100}$ unless it begins to sit in panels, possibly

${ }^{100}$ In Samuel Estreicher and John Sexton, Redefining the Supreme Court's Role (Yale, 1986), proposals are made for changes in the Supreme Court's internal certiorari processes that might, if implemented, result in some increase in the Court's decisional capacity. However, the likelihood of the Court's adopting these proposals does not seem to be great, and even if they were adopted, the additional capacity would not likely be adequate if the inter- 
combined with an increase in the number of Justices. Those steps, however, would likely pose fresh problems and are politically unattractive. Thus, as a practical matter, creative judicial architecture must be focused on the intermediate tier itself and adjustments must be made in its structure that will enable the federal judicial system to carry forward a coherent and harmonious development of federal decisional law.

In matters judicial, the most effective approach to updating improvements, and the one that has usually been taken in AngloAmerican history, is evolutionary rather than revolutionary. In that spirit, this article advances the thesis that Congress, building on the concept already embraced in the Federal Circuit, should move to shift selected categories of appellate business from their dispersal across the dozen regional courts to one or more appellate bodies of nationwide jurisdiction. This article has suggested several categories of business that might be so re-routed and has also suggested structures that might be employed to accommodate this additional nationwide appellate jurisdiction. Time and experience will no doubt bring other categories forward as prospects for nonregional appellate treatment.

An evolution of the federal intermediate appellate tier in this direction will fit comfortably with contemporary circumstances. Just as a large part of everyday American life and business activity has gone nationwide, so must at least some of the appellate decisional process. Much of what was regional is now national. It is no more expensive, time consuming, or inconvenient today for lawyers to submit appeals to a single appellate forum of nationwide jurisdiction than it was for lawyers to submit appeals to regional courts a century ago. Those persons who oppose a development in this direction have a responsibility to suggest more effective means of maintaining doctrinal coherence in federal decisional law. Thus far, however, they have not put forward any ideas that seem more promising than the selective enlargement of non-regional jurisdiction among the U.S. courts of appeals.

mediate appellate structure remains unchanged. 